\title{
Distribution and the current state of Lagochilus acutilobus (Lamiaceae) in connection with the oil and gas sector development in Uzbekistan
}

\author{
"Habibullo F. Shomurodov, "**Akbar Akhmedov, "Shakhnoza U. Saribayeva \\ *Institute of Gene Pool of Plants and Animals, Uzbekistan Academy of Sciences, \\ Bogi-shamol street 232B, Tashkent, Uzbekistan, e-mail: h.shomurodov@mail.ru \\ ${ }^{* *}$ Samarkand State University, Universitet Xiyoboni street 15, Samarkand, Uzbekistan
}

\begin{abstract}
The northern part of the Ustyurt plateau is the main area in Uzbekistan where rare and interesting species Lagochilus acutilobus occurs. The intensified exploration and production of natural gas carried out in recent years by Uzbekistan's National holding company "Uzbekneftegaz" together with the Russian companies "Lukoil" and "Gazprom" is the main factor degrading the soil and vegetation in this region. Trial drilling, expansion and reconstruction of gas pipelines, as well as the accompanying intensification of transport, cause changes in the distribution and resources of the Lagochilus acutilobus populations.

Monitoring of Lagochilus acutilobus was performed in the conditions of strong environmental changes caused by the direct impact of anthropogenic factors enhanced by desiccation of the Aral Sea, the western coast of which bordered previously on the eastern part of the Ustyurt plateau. The species distribution was determined during a series of expeditions in 2011-2013. The maps prepared in the GIS technology show the route and the species occurrence sites located by a GPS receiver. The paper presents the types of plant communities and vegetation complexes in which the studied species occurred. Furthermore, there were determined differences in the abundance of Lagochilus acutilobus in these ecological systems.
\end{abstract}

Key words: anthropogenic impact, bio-diversity conservation, monitoring, GIS, plant communities, population, rare elements of flora, saline soils, species stands, Ustyurt plateau, vegetation cover.

\section{Introduction}

The genus Lagochilus Bunge is represented by 46 species worldwide (www.theplantlist.org). In the flora of Uzbekistan, the genus is represented by 13 (Vvedensky 1961) to 16 (Zukervanik 1987) species.

During the critical survey of the material stored in the herbarium of the Institute of Gene Pool of Plants and Animals of the Academy of Sciences of the Republic of Uzbekistan, the research staff of the Central herbarium added two additional species - Lagochilus diacanthophyllus (Pall.) Benth. and L. platyacanthus Rupr. to the species list of this genus occurring in the flora of Uzbekistan (the material has not been published yet). Thus, at present there are 18 species of the genus Lagochilus occurring in the territory of Uzbekistan.

Taxa of the genus Lagochilus basically occur throughout the territory of Uzbekistan, starting from the deserts to Tian-Shan and Pamir-Alay mountain systems. The majority of species can be found in the Pamir-Alay mountain system - 11 species (Lagochilus seravschanicus Knorr., L. pubescens Vved., L. paulsenii Briq., L. olgae R. Kamelin, L. nevskii Knorr., L. inebrians Bunge, L. kschtutensis Knorr., L. hirsutissimus Vved., L. gypsaceus Vved., L. botschantzevii Kamelin et Zukerv., L. platyacanthus Rupr.); 8 species occur in the south-west of Tian-Shan (Lagochilus setulosus Vved., L. platycalyx Schrenk, L. occultiflorus Rupr., L. knorringianus Pavlov, L. diacantho- 
phyllus (Pall.) Benth., L. seravschanicus Knorr., L. pubescens Vved., L. hirsutissimus Vved.) and 4 species in the Turanian lowland - Lagochilus acutilobus (Ledeb.) Fisch. et C. A. Mey., L. vvedenskyi R. Kam. et Zucker., L. inebrians Bunge, L. gypsaceus Vved.). Three species are common to the Tian-Shan and Pamir-Alay mountains $-L$. seravschanicus, L. pubescens, L. hirsutissimus. The latter species reaches the Alay mountains as the most southern limit of its range. Two species (L. inebrians, L. gypsaceus) have the common area with the Pamir-Alay and the Turanian lowland. There are no species with the common areas with the Tian-Shan mountain and the Turanian lowland.

There are insufficient data in the literature on the distribution and contribution in the vegetation cover of Lagochilus acutilobus. While studying the dynamics of aboveground biomass of the Artemisia terrae-albae Salsola laricifolia community in Betpak-Dala, Kirichenko (1964) reported the presence of Lagochilus acutilobus in the species composition of the community. Later Ikramov (1976) reported that Salsola laricifolia, Artemisia terrae-albae and A. turanica occur as small semi-shrubs and Lagochilus acutilobus as a perennial in the vegetation of Ustyurt and Betpakdala, particularly in Artemisia terrae-albae +Salsola laricifolia communities. Whereas Rachkovskaya and Safranova (2003), who described vegetation cover of the desert regions in Central Asia and Kazakhstan, listed Lagochilus acutilobus only in the composition of rare Artemisia communities in Mangyshlak. According to the aforementioned authors, Lagochilus acutilobus seldom occurs in the composition of the above-mentioned communities; i.e. it occurs with insignificant abundance together with Astragalus ustiurtensis, Crambe eduntula, Haplophyllum versicolor, Tragopogon rubber and Sylene cyri. Momotov $(1953,1973)$ and Sarybaev (1981) also reported that Lagochilus acutilobus occurs sporadically in the vegetation cover of the Ustyurt desert.

As it appears from the above data, so far mainly the distribution of Lagochilus acutilobus was studied in relation to natural ecological factors. Less attention was paid to the importance of anthropogenic factors in the species distribution. Meanwhile, in recent years, Uzbekistan represented by the National holding company "Uzbekneftegaz", together with the Russian companies "Lukoil" and "Gazprom", started to develop large-scale deposits of natural gas on the Ustyurt plateau. Investigation of the perspective areas has already been conducted and reconstruction of gas pipelines has begun. Trial drilling is carried out in the northern part of the Ustyurt plateau where the main population of Lagochilus acutilobus is located. The industrial activity and the related intensification of transport affect the dispersal and changes in the species distribution. These changes occur in the critical ecological conditions connected with the desiccation of the Aral Sea, the western coast of which bordered previously on the eastern part of the Ustyurt plateau.

This paper is devoted to the review of distribution and, partially, to the population strategy of Lagochilus acutilobus (Ledeb.) Fisch. et C. A. Mey. The analysis of the species distribution in relation to intense environmental changes was conducted based on the field observations performed over the last three years during several expeditions on the Ustyurt plateau.

\section{Materials and methods}

Lagochilus acutilobus - a small semi-shrub up to $30 \mathrm{~cm}$ high (Fig. 1). The species grows on sand, takyr, cretaceous exposures, debris and gravel heaps, in the complex with Artemisia and Salsola plant communities. The geographical range of the species covers Pre-Aral deserts, islands of the Aral Sea, Pre-Caspian deserts, Ustyurt, Mangyshlak (Vvedensky 1961). Individual plants are characterised by thin and ramified stalks, rigid at the base, covered with white shiny bark. Leaves are rhomboidal and oblong, spatulate and wedge-shaped at the base. Sessile flowers in axils of 4-6 upper leaves. Narrowly verticillate calyx with narrowly triangular spinose and recurvate denticles. Light pink corolla, ca. $20 \mathrm{~mm}$ long; an upper lip with long straight hairs (Fig. 2). Florescence in May-July and fruit maturity in July-August.

During the expeditions organized in 2011-2013 under the UNDP/GEF project "Integration of biodiversity conservation principles in the oil and gas sector of Uzbekistan", the current state of plant communities was assessed, including rare elements of the Karakalpak Ustyurt flora. The route of expeditions included following sites: 1 - AskhaMazar, 2 - surroundings of Sarykamysh lake, 3 - Asakeaudan, 4 - Karabaur, 5 - Kartbaykum sands, 6 - Lisaya, 7 - Zharynkuduk, 8 - Churuk, 9 - Beleuli, 10 - Bayterek, 11 - Almambet, 12 - Easthigh cliffs, 13 - Kyrkkyz, 14 - Uchsay (Fig. 3). Around camping area and on the way from one point to another were conducted 208 geobotanical descriptions.

Geobotanical descriptions were conducted using a standard technique on a plot of $100 \mathrm{~m}^{2}$ (Lavrenko \& Korchagin 1964, 1972). The location of the surveyed area and vegetation communities with Lagochilus acutilobus were recorded using a handheld GPS unit (Garmin map76C; Garmin Ltd., Kansas). For mapping of field routes and distribution of L. acutilobus, ArcGIS 9.3 software was used (ESRI, 2008). 


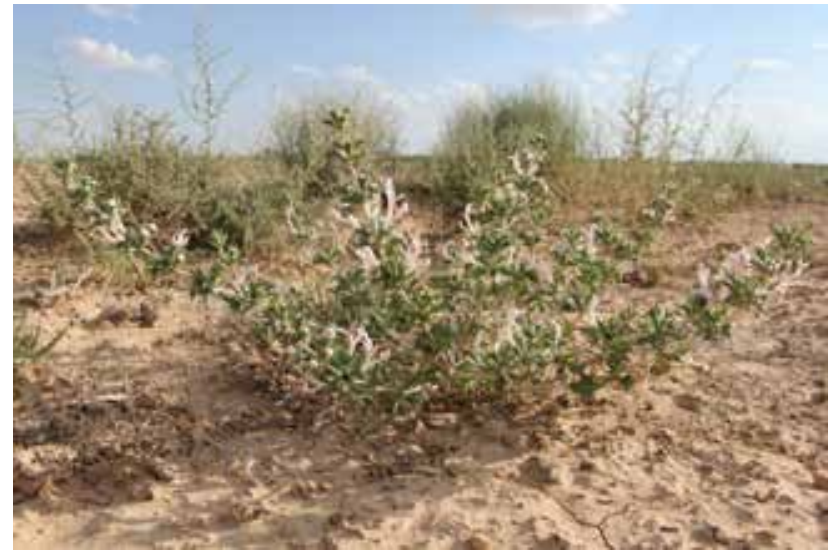

Figure 1. General view of Lagochilus. Ustyurt, May 2013

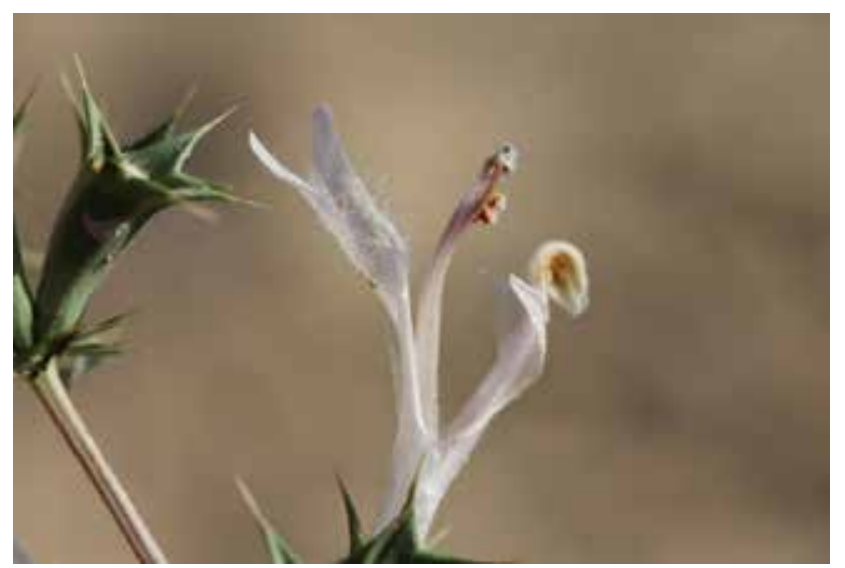

Figure 2. Flowers of Lagochilus acutilobus

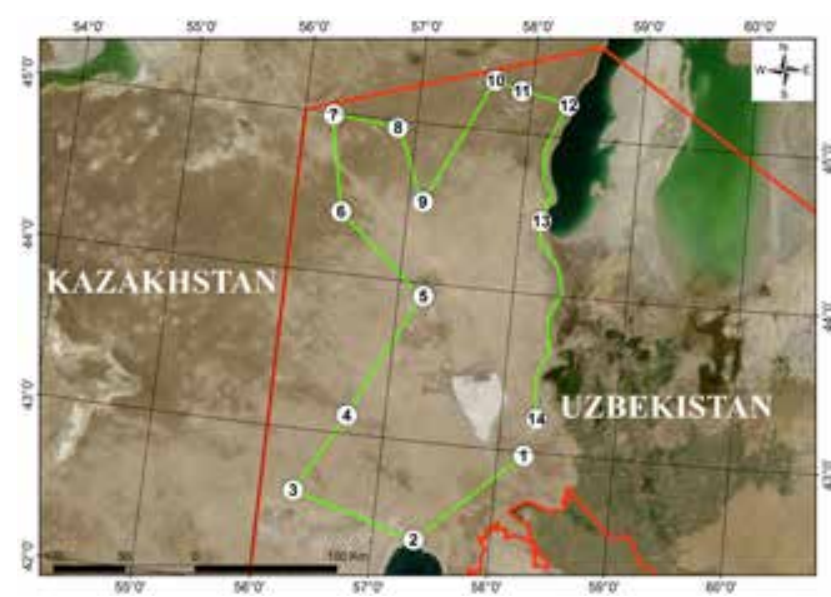

Figure 3. The route of expeditions organized across the Karakalpak Ustyurt (the numbers on the map correspond to the sites mentioned in the text)

\section{Results and discussion}

A total of 185 vascular species from 117 genera and 36 families were identified based on the analysis of the material collected from the surveyed area.

Lagochilus acutilobus occurs occasionally in the surveyed areas. In the south of Karakalpak Ustyurt where Anabasis salsa dominates on saline and solonetz soils, Lagochilus acutilobus basically does not occur, except for a roadside of the Kungrad-Zhaslyk highway where single specimens of L. acutilobus are found due to desalinization of the top horizon of the soil and accumulated atmospheric precipitation. The studied species was not recorded south of the highway on solonetz takyr soils in the vegetation complexes of Anabasis salsa+Artemisia terrae-albae and Haloxylon aphyllum + Artemisia terrae-albae + Anabasis salsa occurring on sandstone massif north of Lake Sarykamysh and on gypsous soils around Asake-auden. The species was also missing in the species composition of Anabasis salsa + Salsola arbusculiformis vegetation complexes in the southwest part of Karakalpak Ustyurt (Karabaur). The species does not occur either in the vegetation cover of the sandstone massif and on Kartbaykum dune saline soils (the central part of Karakalpak Ustyurt). However, single specimens of the species were found on takyr soils in the depression between Karabaur and Zhaslyk regions.

The main area of Lagochilus acutilobus in Uzbekistan is the northern part of Ustyurt (Fig. 4). The species is most abundant in Anabasis salsa + Artemisia terrae-albae + Salsola arbusculiformis vegetation complexes around watering wells of Churuk, Almambet, Beleuli, Bayterek and the adjusted territories. The following three species play the major role in the described complexes of this formation: Anabasis salsa, Artemisia terrae-albae and Salsola arbusculiformis. Phytocoenoses of these species usually form separate spots which are distinguished by the dominance of single species. In this complex, Anabasis sal$s a$ is widespread on saline-solonetz soils, while Artemisia terrae-albae and Salsola arbusculiformis - on light solonetz soils. L. acutilobus occurs both with Anabasis salsa and Salsola arbusculiformis. In the latter community, the species occurs accompanied by grasses in small gaps between compact and tall thickets of outcompeting Salsola arbusculiformis. It forms small groups in dwarf bushes of Anabasis salsa; in some places its density reaches 21 specimens per 10 sq. m (around Beluli), but such abundance rarely occurs.

In general, Lagochilus acutilobus was found in the vegetation cover of Karakalpak Ustyurt in the composition of Artemisia terrae-albae + Salsola arbusculiformis, Anabasis salsa, Artemisia terrae-albae + Anabasis salsa and different grass species associated with Salsola arbusculi- 


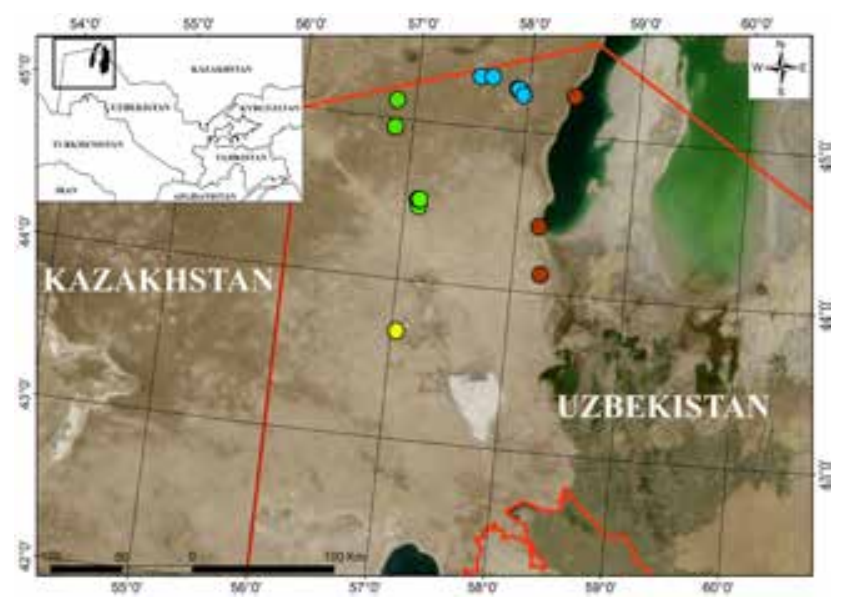

Figure 4. Map of Lagochilus acutilobus distribution in the Uzbekistan part of Ustyurt

Plant communities: $\bigcirc$ - Anabasis salsa, $\bigcirc$ - Artemisia terrae-albae + Salsola arbusculiformis, $\bigcirc$ - Salsola arbusculiformis, $\bigcirc$-Artemisia terrae-albae+ Anabasis salsa

formis communities, where except the dominant species, the following species occur: Anabasis brachiata, Astragalus lasiophyllus, Asparagus breslerianus, Zygophyllum pinnatum, Rheum tataricum, Eremostachys tuberosa, Leontice incerta, Eremopyrum orientale, Lepidium perfoliatum, Alyssum turkestanicum, Halimocnemis villosa, Rhinopetalum karelinii, Ceratocarpus utriculosus, Taktajaniantha pusilla.

In recent years, the critical ecological conditions connected with the desiccation of the Aral Sea have been observed in Ustyurt together the intensification of the oil and gas search works (performeded by "Uzbekneftegaz" and the Russian companies "Lukoil" and "Gazprom") which has advesely affected the biodiversity in general. Further advancement of activities related to gas production will inevitably lead to degradation of soil and vegetation cover in places of well drilling and construction of gas pipelines. Indirectly the biodiversity of the region can also be exposed to degradation through an ecological chain because of polluted subterranean waters and air due to construction and operation of gas fields and gas pipelines.

In the northern subzone of Ustyurt there are many old (Soviet period) and two modern drilling stations. All old drilling stations are characterized by large amounts of scrap metal, garbage and irregular relief. The natural vegetation cover at drilling stations has not been restored until now. Motor traffic is yet another factor negatively affecting the vegetation cover. The network of roads covers the plateau in miscellaneous directions, connecting wells. The roads with heavy traffic have up to 10 tracks, as vehicles moving on clay soil after rain or melted snow destroy the roads, which quickly become almost impassable because of deep tracks. Drivers avoid such sites and create new tracks. Degradation of vegetation continues in such places and its natural regeneration will not possible for a long time. Roads are used by shepherds, hunters, and recently by employees of the gas sector. Roads along which gas workers regularly deliver people and freights are destroyed and covered with a dust layer of ca. $20 \mathrm{~cm}$ thickness, which with constant winds considerably raises the level of dust pollution. All these factors together lead to the deterioration of life conditions of the dominant and rare elements of the Ustyurt flora.

\section{Conclusions}

In the past three years, the current state of several dominant and rare species of Ustyurt has been investigated, including Lagochilus acutilobus under increasing anthropogenic pressure on the biodiversity of the region. As evidenced by the research, the southern limit of Lagochilus acutilobus in Uzbekistan is limited to the central part of Karakalpak Ustyurt. In the south, on saline and solonetz soils and on the sandstone massif to the north of Lake Sarykamysh, and on gypsous soils around Asake-auden, the studied species does not occur in the composition of Anabasis salsa + Artemisia terrae-albae and Haloxylon aphyllum + Artemisia terrae-albae + Anabasis salsa complexes. The species was also absent in the composition of the Anabasis salsa + Salsola arbusculiformis vegetation complex in the southwestern part of Karakalpak Ustyurt. The main area of the species is in the northern subzone of Karakalpak Ustyurt, in the vicinity of watering wells Belule, Bayterek, Churuk, Almambet. It also occurs along the eastern high cliffs (in the northern subzone) forming in some places small groups.

Based on the population strategy, Lagochilus acutilobus is characterized as a rapid-tolerant species with prevalence of tolerant properties. In the deteriorated vegetation communities, especially on the network of not used roads, the species is characterized by the expressed features of rapid reaction. Its rapid reaction is expressed in all phases of vegetative development, predominantly in the high productivity of seeds and increased biomass. The species shows features of tolerance on the saline-solonetz soil in the composition of Artemisia terrae-albae + Anabasis sal$s a+$ Salsola arbusculiformis complexes where anthropogenic pressure is absent or poorly expressed. Its tolerance is characterized by different rates of development of individuals during ontogenesis, by the absence of separate ontogenetic age states and low biomass.

In general, Lagochilus acutilobus is one of the rare plants in Ustyurt, the population of which suffers not only from the global desiccation of the Aral Sea, but also from the development of the oil and gas industry and operation 
of roads in the region in recent years. At present, however, employees of the State Biocontrol at the State Committee on Nature Protection of the Republic of Uzbekistan and a group of scientists of the Academy of Sciences "Saygachy", the purpose of which is to protect the Ustyurt population of saiga (Saiga tatarica). We hope that designation of this wildlife area with the Ustyurt population of saiga will help to save the populations of the only endemic species in Ustyurt - Allium revenii F. O. Khass., Shomuradov \& Kadyrov and a number of species with narrow areas, including Lagochilus acutilobus.

Most of the species from the genus Lagochilus are medicinal herbs characterized by stupefacient, styptic and other properties. They are represented by Lagochilus inebrians, L. gypsaceus, L. setulosus, L. platycalyx, L. platyacanthus Rupr and others (Ikramov 1976). There are no data available in the literature on the pharmacological properties of other species from the genus Lagochilus, in particular L. acutilobus. We therefore believe that it is worthwhile to undertake the research on the application of the studied species in medicine.

\section{Acknowledgement}

The research was performed with the financial support of the UNDP-GEF project "Integration of the biodiversity conservation principles into the oil and gas sector in Uzbekistan". The authors express their gratitude to Dr. K. Sh. Tajibaev and the employees of the Central Herbarium of the Institute of Gene Pool of Plants and Animals of the Academy of Sciences of Uzbekistan, for making the data on the distribution of Lagochilus species available in the form of the herbarium material stored in the herbarium of TASH (Tashkent). We are also grateful to Dr. N. Yu. Beshko for the assistance in mapping the field route and the distribution of Lagochilus acutilobus.

\section{References}

ESRI. 2008. Environmental Systems Research Institute. ArcGIS, Version 9.3.

Genus of Lagochilus. www.theplantlist.org

Ikramov M. I., 1976, Rod lagochilus Srednej Azii [Genus Lagochillus of Central Asia], Izdatielstvo Fan Uzbekskoj S.S.R., Tashkent.
Kirichenko N. G., 1964, Dynamic of above ground vegetation phytomass of Artemisia terrae-albae + Salsola arbusculiformis communities in Betpakdala, Trudy Instituta Botaniki, Akademiia Nauk Kazakhskoi SSR [Proceedings of the Botanical Institute of the Kazakhstan Academy of Sciences], Volume 18, Botanical researches in Kazakhstan, Alma-Ata: 24-29.

Lavrenko E. M. \& Korchagin A. A. (eds.), 1964, Polevaya Geobotanika [Field geobotany], Volume 3, Nauka, Moscow-Leningrad.

Lavrenko E. M. \& Korchagin A. A. (eds.), 1972, Polevaya Geobotanika [Field geobotany], Volume 4. Komarov Institute of Botany, Russian Academy of Sciences, Nauka, Moscow-Leningrad.

Momotov I. F., 1953, Ustyurt's vegetation complex [Rastitelnij kompleks Ustyurta], Izdatelstvo Akademii Nauk Uzbekskoi S. S. R, Tashkent.

Momotov I. F., 1973, Gipsofilnaya rastitelnost [Gypsophylous vegetation], [in:] B. A. Burygin, A. Ya. Butkov, I. I. Granitov, K. Z. Zakirov, R. D. Melnikova, I. F. Momotov, F. N. Russanov, D. K. Saidov (eds.), Rastitelnii pokrov Uzbekistana i puti ego ratsionalnogo ispolzovaniya [Vegetation cover of Uzbekistan and ways for its rational use], Tashkent, Izdatelstvo Akademii Nauk Uzbekskoi S. S. R. 2: 81-192.

Rachkovskaya E. I. \& Safranova I. N., 2003, Rare communities of Artemisia (A. gurganica, A. kaschgarica), [in:] E. I. Rachkovskaya, E. A. Volkova, V. N. Khramtsov (eds.), Botanicheskaia geografiia Kazakhstana i Srednei Azii: v predelakh pustynnoi oblast [Botanical geography of Kazakhstan and Middle Asia: desert region], Komarov Institute of Botany, Russian Academy of Sciences, St. Petersburg.

Sarybayev B., 1981, Flora i rastitelnost vostocnogo cinka Ustyurta [Flora and vegetation of east high cliffs of Ustyurt], Tashkent.

Vvedensky A. I., 1961, Labiatae family, [in:] A.I. Vvedensky (ed.), Flora of Uzbekistan, Tashkent, Academy of Sciences of the Uzbek S. S. R. 5: 364-373.

Zukervanik T. I., 1987, Genus of Lagochilus, [in:] T. A. Adylov (ed.), Opredelitel rastenij Srednei Azii. Kriticeskij konspekt flory, T. 9 [Determinant of plants of Central Asia. Critical synopsis of flora, Vol. 9], (Labiatae, Scrophulariaceae etc.), Tashkent: 119-131. 